\title{
PERAN PEMERINTAH KABUPATEN PANGANDARAN DALAM MEMBERDAYAKAN EKONOMI KREATIF MASYARAKAT
}

\author{
Etty Ratnawati; Nasehudin
}

Program Studi Tadris IPS IAIN Syekh Nurjati Cirebon ettyratnawati@syekhnurjati.ac.id, nasehudin@syekhnurjati.ac.id

\begin{abstract}
Abstrak
Penelitian ini adalah untuk mengetahui peran pemerintah Kabupaten Pangandaran dalam memberdayakan ekonomi kreatif masyarakat. Sementara itu, tujuan khusus dari penelitian ini adalah sebagai berikut: 1) Untuk mengetahui kebijakan pemerintah Kabupaten Pangandaran tentang pengelolaan ekonomi kreatif masyarakat di kawasan wisata. 2) mengetahui pemberdayaan ekonomi kreatif masyarakat di kawasan wisata Pangandaran.

Penelitian ini menggunakan pendekatan kualitatif dengan metode studi kasus. Hal tersebut dikarenakan penelitian ini bersifat kasuistik yang menyangkut sebuah kawasan wisata yang sudah cukup lama berkembang dan telah menjadi kabupaten baru yaitu Pangandaran. Teknik pengumpulan data dalam penelitian ini dilakukan melalui observasi partisipatif, wawancara dan studi dokumentasi

Secara umum penelitian ini dapat disimpulkan bahwa peran pemerintah Kabupaten Pangandaran dalam memberdayakan ekonomi kreatif masyarakat sudah dilakukan baik secara konseptual dalam kebijakan maupun secara taktis dengan melibatkan komponen masyarakat lain. Sedangkan kesimpulan khususnya adalah: 1) Peran pemerintah tentang pengelolaan ekonomi kreatif di kawasan wisata Kabupaten Pangandaran dilakukan melalui sinergitas dengan elemen masyarakat seperti kelompok penggerak pariwisata (Kompepar) dan Bidang UMKM Rumah Kreatif BUMN Pangandaran. 2) Pemberdayaan ekonomi kreatif masyarakat di Kawasan Wisata Pangandaran dilaksanakan oleh pemerintah dalam hal ini Bidang Ekonomi Kreatif Dinas Pariwisata dan Kebudayaan Kebupaten Pangandaran. Hal tersebut guna mengembangkan tiga potensi unggulan dalam bidang ekonomi kreatif diantaranya kuliner, pakaian, dan kerajinan tangan. Pengelolaan ekonomi kreatif di Kabupaten Pangandaran juga menjadi fokus garapan yang penting dalam rangka mendukung ambisi daerah ini sebagai menuju "Wisata Kelas Dunia".
\end{abstract}

Kata Kunci: Pemerintah, Ekonomi Kreatif

\section{Abstract}

This research is to find out the role of the Pangandaran Regency government in empowering the creative economy of the community. Meanwhile, the specific objectives of this study are as follows: 1) To find out the Pangandaran Regency government policy regarding the 
management of the creative economy of the community in the tourist area. 2) find out the empowerment of the creative economy of the community in the Pangandaran tourist area.

This research uses a qualitative approach with a case study method. That is because this research is casuistic that concerns a tourist area that has long been developing and has become a new district, namely Pangandaran. Data collection techniques in this study were carried out through participatory observation, interviews and documentation studies

In general, this research can be concluded that the role of the Pangandaran Regency government in empowering the creative economy of the community has been carried out both conceptually in policy and tactically by involving other community components. While the conclusions in particular are: 1) The role of the government regarding the management of the creative economy in the tourism area of Pangandaran Regency is carried out through synergy with elements of the community such as the tourism driving group (Kompepar) and the SME Sector of the Pangandaran BUMN Creative House. 2) Empowerment of the creative economy of the community in the Pangandaran Tourism Area is carried out by the government in this case the Creative Economy Sector of the Tourism and Culture Office of Pangandaran Regency. This is in order to develop three leading potentials in the creative economy including culinary, clothing, and handicrafts. Creative economy management in Pangandaran Regency is also an important focus of work in order to support the region's ambitions as towards "World Class Tourism".

Keywords: Government, Creative Economy

\section{A. Pendahuluan}

Pangandaran merupakan sebuah wilayah di kawasan selatan Jawa Barat yang sekarang sudah menjadi kabupaten baru hasil pemekaran dari Kabupaten Ciamis. Kawasan ini sudah lama dikenal tempat pariwisata pantai dan laut, bahkan menjadi sektor unggulan dan menjadi ikon Kabupaten Ciamis. Sebagai wilayah pantai, Pangandaran juga memiliki beragam potensi lain yang dapat dikembangkan untuk membangkitkan ekonomi kreatif masyarakat sekitar pantai. Namun, sebesar apapun potensi dan kreativitas masyarakat tidak akan berjalan dengan baik tanpa dukungan pemerintah daerah setempat. Dukungan tersebut dapat berupa kebijakan, program pemberdayaan, maupun yang lainnya. 
Kewenangan daerah baik itu hak maupun kewajiban sebagaimana yang telah diuraikan di atas, pada dasarnya pemerintah daerah harus mampu menjamin masyarakat untuk hidup sejahtera. Upaya untuk mensejahterakan masyarakat dilakukan dalam rangka mengurangi angka kemiskinan. Penanggulangan kemiskinan menurut Penpres No. 15 Tahun 2010 merupakan kebijakan dan program pemerintah serta pemerintah daerah yang dilakukan secara sistematis, terencana dan bersinergi dengan dunia usaha dan masyarakat untuk mengurangi jumlah penduduk miskin dalam rangka meningkatkan kesejahteraan rakyat melalui bantuan sosial, pemberdayaan masyarakat, pemberdayaan Usaha Mikro dan Kecil serta program lain dalam rangka meningkatkan kegiatan ekonomi.

Dari hal di atas maka dalam penelitian ini, akan menggali hal-hal yang belum terpecahan oleh penelitian sebelumnya yakni terkait peranan pemerintah daerah dalam bentuk kebijakan dan pembedayaan masyarakat mengenai potensi ekonomi kreatif di kawasan wisata Pangandaran. Peneliti akan lebih spesifik mengkaji sejauhmana perenan pemerintah sementara pariwasata sudah berlangsung cukup lama jauh sebelum menjadi kabupaten tersendiri. Jangan sampai masyarakat berjalan sendiri tanpa ada sentuhan, peranan atau pemberdayaan dari pemerintah terutama dalam bentuk kebijakan publik.

\section{B. Kajian Teori}

\section{a. Peran Pemerintah}

\section{1) Pemerintah Daerah}

Pembentukan pemerintahan daerah sesuai dengan amanat Pasal 18 Undang-Undang Dasar 1945 menjadi dasar dari berbagai produk undang-undang dan peraturan perundang-undangan lainnya yang mengatur mengenai pemerintah daerah. Sunarno (2008: 54) menjelaskan Undang- Undang tersebut antara lain: 
Undang-undang Nomor 1 Tahun 1945, Undang-undang Nomor 22 Tahun 1948, Undang-undang Nomor 1 Tahun 1957, Undang-undang Nomor 18 Tahun 1965, Undangundang Nomor 5 Tahun 1974, Undang-Undang Nomor 22 Tahun 1999 dan terakhir Undang-undang Nomor 32 Tahun 2004.

Tujuan pembentukan daerah pada dasarnya dimaksudkan untuk meningkatkan pelayanan publik guna mempercepat terwujudnya kesejahteraan masyarakat disamping sebagai sarana pendidikan politik di tingkat lokal. Menurut Suhady dalam Tjandra (2009: 197) Pemerintah (government) ditinjau dari pengertiannya adalah the authoritative direction andadministration of the affairs of men/women in a nation state, city, ect. Dalam bahasa Indonesia sebagai pengarahan dan administrasi yang berwenang atas kegiatan masyarakat dalam sebuah Negara, kota dan sebagainya. Pemerintahan dapat juga diartikan sebagai the governing body of a nation, state, city, etc yaitu lembaga atau badan yang menyelenggarakan pemerintahan Negara, Negara bagian, atau kota dan sebagainya. Pengertianpemerintah dilihat dari sifatnya yaitu pemerintah dalam arti luas meliputi seluruh kekuasaan yaitu kekuasaan legislatif, kekuasaan eksekutif, dan kekuasaan yudikatif. Sedangkan pemerintah dalam arti sempit hanya meliputi cabang kekuasaan eksekutif saja (Tjandra 2009: 197).

\section{2) Kebijakan Pemerintah}

Thomas R. Dye (dalam Afifah \& Yuningsih, 2016: 336) mendefinisikan bahwa: "kebijakan merupakan pilihan-pilihan apapun oleh pemerintah, baik untuk melakukan sesuatu maupun untuk tidak melakukan sesuatu (whatever government choose to do or not to do). Sementara itu, Dye Thomas R., (1976: 1) dalam (Wiranta, 2015:37) Public policy is whatever governments chose 
to do or not to do (Kebijakan publik adalah apapun juga yang dipilih pemerintah, apakah mengerjakan atau tidak mengerjakan sesuatu). Hakikat kebijakan publik adalah respon pemerintah atau Instansi pemerintahan atas tuntutan maupun dukungan masyarakat guna meningkatkan martabat dan kesejahteraan rakyat.

Sedangkan Thomas R. Dye (1995) dalam (Afifah \& Yuningsih, 2016: 336) mendefinisikan kebijakan publik adalah "sebagai segala sesuatu yang dikerjakan pemerintah, mengapa mereka melakukan, dan hasil yang membuat sebuah kehidupan bersama tampil berbeda (what government do, why they do it, and what difference it makes)”. Kebijakan publik tidak akan terlaksana kalau tanpa implementasi kebijakan, oleh karena itu George C. Edwards dalam (Dodopo, 2011: 4) mengemukakan beberapa indikator-indikator yang mempengaruhi implementasi kebijakan antara lain:

a) Komunikasi. Implementasi akan berjalan efektif apabila ukuran-ukuran dan tujuan-tujuan kebijakan dipahami oleh individu-individu yang bertanggungjawab dalam pencapaian tujuan kebijakan.

b) Sumber Daya. Tidak menjadi masalah bagaimana jelas dan konsisten implementasi program dan bagaimana akuratnya komunikasi dikirim. Jika personel yang bertanggungjawab untuk melaksanakan program kekurangan sumberdaya dalam melakukan tugasnya.

c) Disposisi atau Sikap. Salah satu faktor yang mempengaruhi efektifitas implementasi kebijakan adalah sikap implementor.

d) Struktur Birokrasi. Membahas badan pelaksana suatu kebijakan, tidak dapat dilepaskan dari struktur birokrasi.

Dari uraian di atas dapat disimpulkan bahwa kebijkan publik merupakan kebijkan yang dikeluarkan oleh pemerintah 
dalam bentuk peraturan-peraturan yang dapat dijalankan dan laksanakan oleh masyarakat secara langsung. Kebijakan publik juga merupakan bagian dari peranan pemerintah yang sangat penting untuk kelangsungan hidup masyarakat.

\section{b. Pemberdayaan}

Secara etimologis pemberdayaan berasal pada kata dasar "daya" yang berarti kekuatan atau kemampuan. Bertolak dari pengertian tersebut, maka pemberdayaan dapat dimaknai sebagai suatu proses menuju budaya, atau proses untuk memperoleh daya/kekuatan kemampuan, dan atau proses pemberian daya/kekuatan/kemampuan dari pihak yang memiliki daya kepada pihak yang kurang atau belum berdaya (Ambar, 2004: 77). Sedangkan Edi (2009: 210) memberikan penjelasan tentang pemberdayaan adalah suatu cara dengan mana rakyat, organisasi, dan komunitas diarahkan agar mampu menguasai (atau berkuasa atas) kehidupannya.

Menurut catatan Ife dalam bukunya Miftachul Huda (2009: 272-273) disebutkan bahwa pemberdayaan ditujukan untuk meningkatkan kekuasaan (power) dari kelompok masyarakat yang kurang beruntung (disadvantaged). "Empowerment aims to increase the power of the disadvantaged," tulis Ife.

Montagu dan Matson (1987) dalam (Ambar, 2004: 81) yang mengusulkan konsep The Good Community and Competency yang meliputi sembilan konsep komunitas yang baik dan empat komponen kompetensi masyarakat. The Good Community and Competency adalah

1) Setiap anggota masyarakat berinteraksi satu sama lain berdasarkan hubungan pribadi, adanya kelompok juga kelompok primer.

2) Komunitas memiliki otonomi yaitu kemampuan dan kewenangan untuk mengurus kepentingannya sendiri secara bertangung jawab.

3) Memiliki vialibilitas yaitu kemampuan memecahkan masalah sendiri. 
4) Distribusi kekuasaan merata sehingga setiap orang berkesampatan riil, bebas memiliki dan menyatakan kehendaknya.

5) Kesempatan setiap anggota masyarakat untuk berpartisipasi aktif untuk kepentingan bersama.

6) Komunitas memberi makna kepada anggota.

7) Adanya heterogenitas dan beda pendampat.

8) Pelayanan masyarakat ditempatkan sedekat dan secepat kepada yang berkepentingan.

9) Adanya konflik dan managing conflict.

Tahap-tahap pemberdayaan, sebagaimana disampaikan di muka bahwa proses belajar alam rangka pemberdayaan masyarakat akan berlangsung secara bertahap. Tahap-tahap yang harus dilalui tersebut meliputi:

1) Tahap penyadaran dan pembentukan perilaku menuju perilaku sadar dan peduli sehingga merasa membutuhkan peningkatan kapasitas diri.

2) Tahap transformasi kemampuan berupa wawasan pengetahuan, kecakapan-keterampilan agar terbuka wawasan dan memberikan keterampilan dasar sehingga dapat mengambil peran didalam pembangunan.

3) Tahap peningkatan kemampuan intelektual, kecakapanketerampilan sehingga terbentuklah inisiatif dan kemampuan inovatif untuk mengantarkan pada kemandirian.

Dari uraian di atas maka dapat ditindaklanjuti bahwa pemberdayaan harus mampu memberikan stimulasi terhadap munculnya ketahanan dan kemandirian rakyat yang rentan serta memiliki keterbatasan dalam akses jenis-jenis pekerjaan dan penghasilan yang layak.

\section{c. Ekonomi Kreatif}

Dalam buku John Howkins (2001: 8) dalam bukunya The Creative Economy: How People Make Money sebagaimana dikutif 
Policy Research Group (2013: 3), yaitu" the transactions of creative products that have an economic good or service that results from creativity and has economic value". Dalam artian bahwa transaksi produk kreatif yang memiliki barang atau jasa ekonomi yang dihasilkan dari kreativitas dan memiliki nilai ekonomi. Ekonomi kreatif bukan hanya pada sebatas kemampuan menghasilkan suatu produk ekonomi namun juga harus bernilai sehingga mampu bersaingan di pasaran.

Definsi lain juga dikeluarkan oleh Departemen Kebudayaan, Media dan Olahraga Inggris atau Department of Culture, Media and Sport (DCMS, 1998,p.3) yang dikutif oleh Policy Research Group (2013: 3), yakni bahwa: "those industries which have their origin in individual creativity, skill and talent and which have a potential for wealth and job creation through the generation and exploitation of intellectual property". Industri-industri yang memiliki asal-usul mereka dalam kreativitas, keterampilan dan bakat individu dan yang memiliki potensi kekayaan dan penciptaan lapangan kerja melalui generasi dan eksploitasi kekayaan intelektual.

Hal yang harus digarisbawahi dari ekonomi kreatif yaitu tentang bagaimana karya atau produk tersebut merupakan kekayaan intelektual dan harus dilindungi. Sementara itu, konferensi PBB tentang Perdagangan dan Pembangunan (UNCTAD) sebagaimana dikutif oleh The Creative Nova Scotia Leadership Council .(2012: 5) menyatakan bahwa:

Is an evolving concept based on creative assets potentially generating economic growth and development (2008): a) It can foster income generation, job creation and export earnings while promoting social inclusion, cultural diversity and human development. b) It embraces economic, cultural and social aspects interacting with technology, intellectual property and tourism objectives. c) 
It is a set of knowledge-based economic activities with a development dimension and crosscutting linkages at macro and micro levels to the overall economy. d) It is a feasible development option for innovation, multidisciplinary policy responses and inter-ministerial action. e) At the heart of the creative economy are the creative industries.

Keberaadaan ekonomi kreatif tidak sepenuhnya berjalan mulus karena kerap mengalami kegagala sebagaimana hasil analisi penelitian internasional dari Boyke R. Purnomo \& Stein Kristiansen (2017) yang berjudul Economic Reasoning and Creative Industries Progress, yang menyatakan bahwa:

We identify three types of market failure in creative industries due to information asymmetries, namely 'lemon markets', 'concentration markets' and 'speculator markets'. We propose further research on subjective reasoning among buyers and how prices are set; how artistic and economic logics of producers relate to business performance; and how creative industries' growth can be facilitated, not least in poor economies with a high need for employment creation.

Terdapat tiga jenis kegagalan pasar dalam industri kreatif karena asimetri informasi, yaitu 'pasar lemon', 'pasar konsentrasi', dan 'pasar spekulator'. Untuk itu, perlu ditetapkan agar pertumbuhan industri kreatif dapat difasilitasi, tidak terkecuali di negara miskin dengan kebutuhan tinggi untuk penciptaan lapangan kerja.

Dari uraian di atas dapat diketahui bahwa ekonomi kreatif merupakan manifestasi dari semangat bertahan hidup yang sangat penting bagi negara-negara maju dan juga menawarkan peluang yang sama untuk negaranegara berkembang. Di dalam ekonomi kreatif terdapat pesan yakni pemanfaatan cadangan sumber daya yang bukan hanya terbarukan, bahkan tak terbatas, yaitu ide, talenta dan 
kreativitas. Untuk itu, ekonomi kreatif merupakan sebuah konsep ekonomi yang mengintensifkan informasi dan kreativitas, mengandalkan ide dan stock of knowledge dari sumber daya manusia (SDM) sebagai faktor produksi utama dalam kegiatan ekonominya.

\section{Metode Penelitian}

Penelitian ini menggunakan pendekatan kualitatif dengan metode studi kasus. Hal tersebut dikarenakan penelitian ini bersifat kasuistik yang menyangkut sebuah kawasan wisata yang sudah cukup lama berkembang dan telah menjadi kabupaten baru yaitu Pangandaran. Menurut Creswell (2014: 4) bahwa"penelitian kualitatif untuk mengeksplorasi dan memahami makna yang oleh sejumlah individu atau sekelompok orang yang dianggap berasal dari masalah sosial atau kemasyarakatan." Menurut Yin (2013, hal. 17) studi kasus memungkinkan peneliti untuk mempertahankan karakteristik holistik dan bermakna peristiwa-peristiwa kehidupan nyata seperti siklus kehidupan seseorang, proses organisasional dan manajerial, perubahan lingkungan sosial. Selama penelitian berlangsung, peneliti menggali secara natural, holistik dan mendalam tentang kebijakan pemerintah Kabupaten Pangandaran tentang pengelolaan ekonomi kreatif kawasan wisata.

Teknik pengumpulan data dalam penelitian ini dilakukan melalui observasi partisipatif, wawancara dan studi dokumentasi. Berikut merupakan langkah-langkah teknik pengumpulan data selama di lapangan:

a. Observasi Partisipatif

Dalam observasi ini, peneliti telah mengamati kejadian di lapangan yaitu di kawasan wisata Pangandaran khususunya di sekitar Pantai Barat, Ke kantor Dinas Pariwisata dan Kebudayaan Kabupaten Pangandaran, Kelompok Penggerak Pariwisata (Kompepar), Rumah Kraetif BUMN, dan DPRD Kabupaten Pangandaran. Secara prinsip, Creswell (2014: 267) menyatakan bahwa"peneliti langsung 
kelapangan untuk mengamati perilaku dan aktivitas individu-individu di lokasi penelitian." Selama di lapangan, peneliti berbaur dengan lingkungan, peneliti menjadwal untuk mengunjungi dan memperhatikan situasi. Observasi ini akan dilakukan di lokasi strategis para pelaku usaha ekonomi kreatif di kawasan wisata Pangandaran, seta kantor pemerintah Kabupaten Pangandaran, terutama dinas pariwisata.

b. Wawancara Mendalam

Proses wawancara yang telah dilakukan yaitu para informan diantaranya kepala bidang ekonomi kreatif Ke Kantor Dinas Pariwisata dan Kebudayaan Kabupaten Pangandaran, Ketua Kelompok Penggerak Pariwisata (Kompepar), Aktivis UMKM Rumah Kreatif BUMN Pangandaran dan perwakilan dari pelaku usaha. Menurut Creswell (2014: 267) "peneliti melakukan face to face interview (wawancara langsung) dengan partisipan, mewawancara mereka dengan pertanyaan yang terstruktur dan bersifat terbuka sehingga memunculkan pandangan dan opini dari para partisipan". Para informan yang akan diwawancarai diantaranya para pelaku usaha ekonomi kreatif, para pemangku kebijakan pemerintah Kabupaten Pangandaran baik eksekutif maupun legislatif.

c. Studi Dokumentasi

Dokumentasi yang didapat oleh peneliti, diantaranya beberapa Peraturan Daerah yang berkiatan dengan Pengelolaan Wisata Kabupaten Pangandaran dan dokumen-dokumen dari Dinas Pariwisata dan Kebuayaan khusunya tentang kegiatan pemberdayaan ekonomi kreatif. Menurut Creswell (2014: 267-270)"dokumen ini bias berupa dokumen publik (seperti koran, makalah, laporan kantor) ataupun dokumen privat (seperti buku harian, diary, surat, e-mail)". Dokumen yang dibutuhkan oleh peneliti diantaranya draf Peraturan Daerah Kabupaten Pangandaran tentang pengelolaan wisata dan usaha kecil menengah, profil dinas pariwisata atau dinas terkait lainnya.

\section{Hasil dan Pembahasan Penelitian}




\section{a. Peran Pemerintah Kabupaten Pangandaran}

Pembentukan pemerintahan daerah sesuai dengan amanat Pasal 18 Undang-Undang Dasar 1945 menjadi dasar dari berbagai produk undang-undang dan peraturan perundang-undangan lainnya yang mengatur mengenai pemerintah daerah. Tujuan pembentukan daerah pada dasarnya dimaksudkan untuk meningkatkan pelayanan publik guna mempercepat terwujudnya kesejahteraan masyarakat disamping sebagai sarana pendidikan politik di tingkat lokal.

Dalam penelitian ini, dikaji mengenai salah satu Daerah Otonomi Baru yakni Kabupaten Pangandaran yang memiliki potensi wisata dan ekonomi kreatif masyarakatnya. Namun, peran pemerintah dalam berbagai kebijakan khusunya masih beradaftasi dengan sistem dan prinsip otonomi daerah. Pasal 1 angka 2 Undang-Undang Nomor 32 Tahun 2004 tentang Pemerintah Daerah menjelaskan bahwa yang dimaksud pemerintahan daerah adalah penyelenggaraan urusan pemerintahan oleh pemerintah daerah dan DPRD menurut asas otonomi dan tugas pembantuan dengan prinsip otonomi seluasluasnya dalam sistem dan prinsip Negara Kesatuan Republik Indonesia sebagaimana dimaksud dalam Undang-Undang Dasar Negara Republik Negara Tahun 1945.

Pemerintah Kabupaten Pangandaran masih memiliki keterbatasan dalam mengeluarkan kebijakan dalam bentuk peraturan daerah. Untuk itu, hal-hal yang krusial misalnya sektor ekonomi kreatif masih menjadi bagian dari Penyelenggaraan Kepariwisataan. Maka bidang ekonomi kraetif saat ini merupakan bagian dari dinas pariwisata dan kebuadayaan Kabupaten Pangandaran. Namun, menurut Ketua Kelompok Penggerak Pariwisata Kabupaten Pangandaran Bapak Edi Rusmiadi (Wawancara, 7 Agustus 2018) menyatakan bahwa "Dampak dari Otonomi Daerah kemudian pembentukan Kabupatan Baru. Maka, kami sebagai putra daerah 
sangat luar biasa dan mendukung terbentuknya Kabupaten Pangandaran".

Walaupun pemerintah daerah belum begitu produktif dalam membuat kebijakan publik, tetapi pembentukan kabupaten pangandaran disambut baik oleh seluruh elemen masyarakat. Menurut Kabid Kabid Ekonomi Kreatif Dinas Pariwisata dan Kebudayaan Bapak Megi R (Wawancara, 6 Agustus 2018) "Ketika zaman Ciamis, Pangandaran hanya dikenal sebagai pantai pangandaran saja. Sehingga sangat mendukung terbentuknya Kabupaten Baru ini, yang dimulai dari desa, atas aspirasi dari dewan pemekaran sehingga 10 Kecamatan menyatakan bergabung.

Kebijakan khusus mengenai kepariwisataan di Kabupaten Pangandaran termuat dalam Perda No 14 tentang penyelanggaraan kepariwisataan. dalam Pasal 2 Kepariwisataan tentang tujuan di point $\mathrm{c}$ dan h merupakan tujuan yang menjadi focus utama dalam penelitian. Sebagaimana yang dikaji bahwa adanya pariwisata sebaiknya memperluas dan memeratakan kesempatan usaha dan lapangan kerja serta mengoptimalkan pendayagunaan produksi lokal. Sedangkan dalam Pasal 4 dijelaskan mengenai Penyelenggaraan Kepariwisataan yang berkaiatn dengan industri kreatif yaitu point $\mathrm{f}$ usaha jasa makanan dan minuman. Ini pun yang termasuk 3 (tiga) bidang pengembangan unggulan industry kreatif di Pangandaran.

Artinya, peran pemerintah Kabupaten Pangandaran dalam bentuk kebijakan publik mengenai ekonomi kreatif yang bagian dari sektor kepariwisataan belum secara detail di atur. Dengan kata lain, industry kreatif yang berkembang di lapangan tidak harus menunggu aturan atau kebijakan khusus pemerintah. Karena jika masyarakat memiliki kreatifitas dalam bidang ekonomi kreatif, pemerintah tidak akan menghambat pasti akan mendukung bahkan memfasilitasi. Hal ini diakui oleh salah satu responden yakni Andi Nurron sebagai Aktivis UMKM Rumah Kreatif BUMN Pangandaran (Wawancara, 3 
Agustus 2018): "Pemerintah sudah mendukung melalui sejumlah program dan bantuan perizinan (PIRT, hala, dll)".

Dari uraian di atas dapat disimpulkan bahwa peran pemerintah tentang pengelolaan ekonomi kreatif di kawasan wisata Kabupaten Pangandaran dilakukan melalui sinergitas dengan elemen masyarakat khususnya Kelompok Penggerak Pariwisata (Kompepar) dan Rumah Kraetif BUMN Pangandaran. Selain itu, terdapat kebijakan pemerintah dalam bentuk Peraturan Daerah yang secara langsung maupun tidak langsung berkaitan dengan sektor wisata dan ekonomi kreatif diantaranya Peraturan Daerah Kabupaten Pangandaran Nomor 3 Tahun 2016 Retribusi Tempat Rekreasi dan Olah raga, Peraturan Daerah Kabupaten Pangandaran Nomor 14 Tahun 2015 Tentang Penyelenggaraan Kepariwisataan, dan Peraturan Daerah Kabupaten Pangandaran Nomor 42 Tahun 2016 Ketertiban, Kebersihan, Dan Keindahann.

\section{b. Pemberdayaan Ekonomi Kreatif di Kawasan Wisata Pangandaran}

1) Permasalahan Ekonomi Kreatif di Pangandaran

Tiga bidang garapan ekonomi kreatif di Pangandaran yakni kuliner, fashion, dan kerajinan tangan sudah berusaha untuk tetap dikembangkan karena tiga bidang itu merupakan fokus utama sesuai dengan potensi alam dan kemampuan sumber daya manusia di Pangandaran. Hasilnya pun sudah banyak membantu masyarakat khusus pelaku usaha serta membantu pemerintah dalam promosi kawasan wisata. Namun, salah satu masalah yang muncul dari sektor ekonomi kreatif di kawasan wisata Pangandaran adalah barang-barang industri kreatif belum di pasarkan secara umum. Misalnya hasil kerajinan tangan (bahan dari batok, kelapa dan bambu), pakaian khas pangandaran (seperti batik koja), maupun kuliner khusus di Pangandaran (seperti gula semut dan pindang gunung). Selain karena harganya yang cukup tinggi juga hanya 
terdapat ditempat ekslusif seperti rumah kreatif atau ketika hanya ada pameran-pameran saja.

Di Indonesia melalui badan ekonomi kreatif (Bekraf) mengkategorikan 16 jenis ekonomi kreatif, yakni:

a) Aplikasi dan Pengembang Permainan

b) Arsitektur

c) Desain Interior

d) Desain Komunikasi Visual

e) Desain Produk

f) Fashion

g) Film, Animasi, dan Video

h) Fotografi

i) Kriya

j) Kuliner

k) Musik

1) Penerbitan

m)Periklanan

n) Seni Pertunjukan

o) Seni Rupa

p) Televisi dan Radio. (Sabdarini, 2018: 1)

Salah satu masalah yang muncul dari sektor ekonomi kreatif di kawasan wisata Pangandaran adalah barang-barang industri kreatif belum di pasarkan secara umum. Misalnya hasil kerajinan tangan (bahan dari batok, kelapa dan bambu), pakaian khas pangandaran (seperti batik koja), maupun kuliner khusus di Pangandaran (seperti gula semut dan pindang gunung). Selain karena harganya yang cukup tinggi juga hanya terdapat ditempat ekslusif seperti rumah kreatif atau ketika hanya ada pameranpameran saja. 
Hasil FGD (23 November 2018) dengan elemen masyarakat seperti penggerak pariwisata dan pelaku usaha ekonomi kreatif menemukan beberapa temuan baru diantaranya:

a) Belum jelasnya sekor-sektor usaha atau bidang apa saja yang dikategorikan sebagai ekonomi kreatif.

b) Terdapat tumpang tindih antar dinas terkait mengenai garapan sektor ekonomi kreatif, misalnya ketika bidang ekonomi kreatif dinas pariwisata melakukan pembinaan mengenai pelatihan kerajinan tangan, batik, gula semut, pindang gunung, juice honje, dinas UMKM perindustrian dan perdagangan juga itu mengklaim sebagai garapan mereka.

c) Usaha kreatif yang dilakukan oleh masyarakat belum tentu memiliki nilai jual, walau itu produk yang unik dan berkualitas tetapi belum tentu ada itu laku untuk dipasarkan.

d) Pelatihan dan pemberdayaan yang dilakukan oleh pihak terkait jangan hanya sebatas pada proses produksi atau pembuatan barang saja, seharusnya sudah lebih maju misalnya mendesain dari sisi pengemasan. Hal tersebut penting agar produk usaha ekonomi kreatif tersebut dapat menarik para pembeli.

Dari uraian di atas dapat diketahui, bahwa sektor ekonomi kreatif di Pangandaran memiliki peluang yang besar untuk dikembangkan karena didukung oleh banyak potensi alam dan potensi pengembangan ekonomi kreatif. Namun ternyata pengelolaan dan pengembangannya tidak mudah dilakukan, ada beberapa kendala yang dihadapi, diantaranya:

a) Melimpahnya bahan baku kurang didukung oleh alat-alat yang canggih dalam pengolahan. Seperti mesin untuk memotong sebagai bahan kerajinan batok dan bambu. Contoh: butuh bahan baku dari alam. Kendala secara teknis dalam pengembangan ekonomi kreatif yaitu Tidak adanya mesin pembelah bamboo/batok kelapa serta bahan limbah lainnya. 
b) Hasil-hasil dari pelaku usaha ekonomi kreatif belum dipasarkan secara luas. Karya ekonomi kraetif seperti kuliner, kerajinan tangan,dan fashion hanya dipasarkan ditempat-tempat khusus. Sedangkan yang banyak dan mudah ditemukan oleh wisatawan adalah produk-produk yang umum yang tidak jauh berbeda dengan tempat lain seperti, kopi saset, pop mie, pakaian pantai, pernak pernik pantai. Sementara yang mencirikan Pangandaranya masih jarang dijumpai ditempat umum seperti pindang gunung, gula semut, dan batik koja (batik khas pangandaran).

2) Pemberdayaan Masyarakat dalam bidang Ekonomi Kreatif

Pemberdayaan ekonomi kreatif sudah dilakukan dengan berbagai cara, walau fokus garapannya baru sektor pelatihan produk. Kedepannya harus ada yang memikirkan strategi terkait teknik pemasaran. Secara prinsipil, pemberdayaan menuurt Edi (2009: 210): "suatu cara dengan mana rakyat, organisasi, dan komunitas diarahkan agar mampu menguasai (atau berkuasa atas) kehidupannya".Miftachul Huda (2009: 272-273) disebutkan bahwa pemberdayaan ditujukan untuk meningkatkan kekuasaan (power) dari kelompok masyarakat yang kurang beruntung (disadvantaged). "Empowerment aims to increase the power of thedisadvantaged,"

Pemberdayaan ekonomi kreatif di pangandaran sudah dilakukan dengan berbagai cara, walau fokus garapannya baru sektor pelatihan produk. Kedepannya harus ada yang memikirkan strategi terkait teknik pemasaran. Menurut Kabid Kabid Ekonomi Kreatif Dinas Pariwisata dan Kebudayaan Bapak Megi R (Wawancara, 6 Agustus 2018) mengatakan bahwa "upaya pemberdayaan masyarakat dilakukan dengan adanya sinergitas antara pemerintah pusat, masyarakat, dan pemerintah daerah. Intinya ingin meningkatkan ekonomi masyarakat, menarik banyak wisatawan". 
Data yang di dapat peneliti menunjukan bahwa berbagai upaya dilakukan oleh pemerintah dalam hal ini Bidang Ekonomi Kreatif Dinas Pariwisata dan Kebudayaan Kabupaten Pangandaran. Adapun kegiatan tersebut seperti:

1) Pelatihan Kerajinan Batik Tahun 2018 dilaksanan selama tiga hari yakni tanggal 5 sampai dengan 7 Maret 2018.

2) Pelatihan Kerajinan Anyam. Tahun 2018 dilaksanan selama tiga hari yakni tanggal 5 sampai dengan 7 Maret 2018. Peserta berjumlah 10 orang berasal dari anggota P2KWSS wilayah Kecamatan Cimerak

3) Pelatihan Kerajinan Ukiran Tahun 2018 dilaksanakan selama tiga hari yakni tanggal 18 samapai dengan 20 April 2018.

4) Pelatihan Kerajinan Tenun Mei 2018

5) Pelatihan Desain Produk Juni 2018

Namun, peneliti menganalisis kegiatan pemberdayaan masyarakat di pangandaran semuanya baru bersifat teknis karena fokus pada pelatihhan-pelatihan produk. Belum sampai pada tahaptahap pemberdayaan, sebagaimana proses belajar dalam rangka pemberdayaan masyarakat akan berlangsung secara bertahap.

Masalah lain yang ditemukan pada saat peneliti melakukan FGD (23 November 2018) ternyata kegiatan pemberdayaan yang dilakukan oleh bidang Dinas Pariwisata khusus bidang ekonomi kreatif, juga digarap oleh dinas lain seperti UMKM dan Perindustrian. Hal ini memang seakan masih terdapat perebutan garapan dan wewenang antara dinas yang satu dengan dinas yang lainnya.

Dari uraian di atas dapat disimpulkan, bahwa pemberdayaan ekonomi kreatif masyarakat di Kawasan Wisata Pangandaran dilaksanakan oleh pemerintah dalam hal ini Bidang Ekonomi Kreatif Dinas Pariwisata dan Kebudayaan Kebupaten Pangandaran melelui berbagai kegiatan diantaranya: Pelatihan Kerajinan Batik, 
Pelatihan Kerajinan Anyam, Pelatihan Kerajinan Ukiran, Pelatihan Pelatihan Desain Produk, dan Kerajinan Tenun. Hal tersebut guna mengembangkan tiga potensi unggulan dalam bidang ekonomi kreatif diantaranya kuliner, pakaian dan kerajinan tangan. Pengelolaan ekonomi kreatif di Kabupaten Pangandaran juga menjadi fokus garapan yang penting dalam rangka mendukung ambisi daerah ini sebagai menuju "Wisata Kelas Dunia".

\section{E. Kesimpulan}

Secara umum penelitian ini dapat disimpulkan bahwa peran pemerintah Kabupaten Pangandaran dalam memberdayakan ekonomi kreatif masyarakat sudah dilakukan baik secara konseptual dalam kebijakan maupun secara taktis dengan melibatkan kompenen masyarakat lain. Sedangkan kesimpulan khususnya adalah sebagai berikut:

1) Peran pemerintah tentang pengelolaan ekonomi kreatif di kawasan wisata Kabupaten Pangandaran dilakukan melalui sinergitas dengan elemen masyarakat seperti kelompok penggerak pariwisata (Kompepar) dan Bidang UMKM Rumah Kreatif BUMN Pangandaran. Selain itu, terdapat kebijakan pemerintah dalam bentuk Peraturan Daerah yang secara langsung maupun tidak langsung berdampak pada sektor wisata dan ekonomi kreatif diantaranya Peraturan Daerah Kabupaten Pangandaran Nomor 3 Tahun 2016 Retribusi Tempat Rekreasidan Olahraga, Peraturan Daerah Kabupaten Pangandaran Nomor 14 Tahun 2015 Tentang Penyelenggaraan Kepariwisataan, dan Peraturan Daerah Kabupaten Pangandaran Nomor 42 Tahun 2016 Ketertiban, Kebersihan, dan Keindahann.

2) Pemberdayaan ekonomi kreatif masyarakat di Kawasan Wisata Pangandaran dilaksanakan oleh pemerintah dalam hal ini Bidang Ekonomi Kreatif Dinas Pariwisata dan Kebudayaan Kebupaten Pangandaran melelui berbagai kegaiatan diantaranya: Pelatihan 
Kerajinan Batik, Pelatihan Kerajinan Anyam, Pelatihan Kerajinan Ukiran, Pelatihan Pelatihan Desain Produk, dan Kerajinan Tenun. Hal tersebut guna mengembangkan tiga potensi unggulan dalam bidang ekonomi kreatif diantaranya kuliner, pakaian, dan kerajinan tangan. Pengelolaan ekonomi kreatif di Kabupaten Pangandaran juga menjadi fokus garapan yang penting dalam rangka mendukung ambisi daerah ini sebagai menuju "Wisata Kelas Dunia".

\section{Daftar Pustaka}

Afifah, D. F., \& Neneng Yani Yuningsih. (2016, Oktober ). Analisis Kebijakan Pemerintah Tentang Pencegahan Dan Penanganan Korban Perdagangan (Trafficking) Perempuan Dan Anak Di Seminar Sistem Perekonomian Nasional menurut pasal 33 UUD 1945 (pp. 1-8). Kabupaten Cianjur.Jurnal Ilmu Pemerintahan, Vol.2 No.2, 330-360.

Ambar Teguh Sulistiyani. (2004). Kemitraan dan Model-model Pemberdayaan. Gava Media: Yogyakarta.

Boyke R. Purnomo \& Stein Kristiansen. (2017). Economic Reasoning And Creative Industries Progres. Creative Industries Journal, 11:1, 3-21, DOI: 10.1080/17510694.2017.1403206

Creswell, John W., (2014). Research Design: Pendekatan Kualitatif, Kuantitatif, dan Mixed. Yogyakarta: Pustaka Pelajar.

Darto. (2017). Pemberdayaan Masyarakat Dalam Upaya Pengembangan Desa Wisata Di Kecamatan Cijulang Kabupaten Pangandaran Provinsi Jawa Barat. . Program Studi Administrasi Publik, Fakultas Ilmu Sosial dan Ilmu Politik Universitas Padjadjaran. Bandung: Majalah Ilmiah UNIKOM Vol.15 No. 1 hal. 61-70.

Dodopo, H. (2011). Implementasi Kebijakan Pemerintah Daerah Dalam Pelayanan Pembuatan Kartu Keluarga ( Suatu Studi di Dinas Kependudukan Dan Pencatatan Sipil Kabupaten Halmahera Utara ).

Edi Suharto. (2009). Definisi Pemberdayaan Membangun Masyarakat Memberdayakan Rakyat Kajian Strategis Pembangunan Kesejahteraan Sosial \& Pekerjaan Sosial. Bandung: Refika Aditama. 
Ginting, AM, dkk. (2016). Strategi Pengembangan Ekonomi Kreatif Di Daerah Dalam Mendukung Perekonomian Nasional (Studi di Provinsi Jawa Barat dan Nusa Tenggara Barat). Jakarta:Pusat Penelitian Badan Keahlian Dewan Perwakilan Rakyat Republik Indonesia.

Miftachul Huda. (2009). Pekerjaan Sosial dan Kesejahteraan Sosial: Sebuah Pengantar. Yogyakarta: Pustaka Pelajar.

Muftiadi, A. (2017). Pengembangan Desa Wisata Dan Potensinya di Kabupaten Pangandaran. Bandung: Department of Business Administration Faculty of Social and Political Sciences Universitas Padjadjaran. Jurnal AdBispreneur Vol. 2, No. 2, Agustus 2017 Hal. 117-124.

Policy Research Group (2013). The Creative Economy: Key Concepts and Literature Review Highlights. Nova Scotia: Creative Nova Scotia Leadership Council in Partnership with the Nova Scotia Department of Communities, Culture, and Heritage.

Sabdarini, Irene Tatyana. 27 March 2018, Profil Usaha/Perusahaan 16 Subsektor Ekonomi Kreatif. Bekraf. http://www.bekraf.go.id/berita/page/17/profilusahaperusahaan-16-subsektor-ekonomi-kreatif (diakses, 12 Oktober 2018).

Saksono, H. (2012). Ekonomi Kreatif: Talenta Baru Pemicu Daya Saing Daerah. Jakarta: Pusat Penelitian dan Pengembangan Pemerintahan Umum dan Kependudukan Badan Penelitian dan Pengembangan (BPP) - Kementerian Dalam Neger. Jurnal Bina Praja Volume 4 No. 2 Juni 2012: 93 - 104.

Sidauruk, R. (2013). Peningkatan Peran Pemerintah Daerah Dalam Rangka Pengembangan Ekonomi Kreatif di Provinsi Jawa Barat. Jakarta: Badan Penelitian dan Pengembangan Kementerian Dalam Negeri.

Sunarno, Siswanto. (2008). Hukum Pemerintahan Daerah di Indonesia, Sinar Grafika Offset, Jakarta.

The Creative Nova Scotia Leadership Council (CNSLC).(2012). Creative Economy Literature Review. The Creative Nova Scotia Leadership Council In partnership with Nova Scotia Department of Communities, Culture and Heritage.

Tjandra, Riawan. (2009). Hukum Keuangan Negara, Cetakan Ke-II, Jakarta: P.T. Gramedia Widiasarana. 
UUD Negara Republik Indonesia Tahun 1945. (2014). Kepaniteraan dan Sekretariat Jenderal Mahkamah Konsitusi RI.

UU No. 32 Tahun 2004 tentang Sistem Pemerintahan Daerah.

Yalia, Mulyono. (2015). Implementasi Kebijakan Pengembangan Dan Pemberdayaan Lembaga Komunikasi Sosial (Studi Pada Kelompok Informasi Masyarakat (KIM) Di Kabupaten Pangandaran Jawa Barat). Bandung: Balai Pengkajian dan Pengembangan Komunikasi dan Informatika (BPPKI). Jurnal Penelitian Komunikasi dan Opini Publik Vol. 19 No. 1, April 2015: 29-41.

Yin, R.K. (2013). Studi Kasus Desain \& Metode. (M. D. Mudzakir, Trans.) Depok: PT Rajagrafindo Persada. 